УДК 631.82

(C) 2013

Глущенко Л. Д., кандидат сільськогосподарських наук, Олепір Р. В., Лень О. І., стариі наукові співробітники, Вакуленко В. М., лаборант

Полтавська державна сільськогосподарська дослідна станція ім. М. І. Вавилова Інституту свинарства і АПВ НААНУ

Біланович О. Л., спеціаліст

Полтавський центр «Облдержродючість»

Котвіцький Б. Б., кандидат сільськогосподарських наук

Волинська державна сільськогосподарська дослідна станція

Інституту сільського господарства Західного Полісся НААНУ

\title{
ЕФЕКТИВНІСТЬ ЗАСТОСУВАННЯ ВОДОРОЗЧИННИХ ДОБРИВ ПІД ОСНОВНІ СІЛЬСЬКОГОСПОДАРСЬКІ КУЛЬТУРИ ЗА УМОВ ЗМІНИ КЛІМАТУ
}

\section{Рецензент - кандидат сільськогосподарських наук Л. С. Сремко}

За останні роки на Полтавщчині в погодних умовах суттєво змінилися температурний і водний режими. Протягом вететаційного періоду 2008-2012 років спостерігалося підвищення середньомісячної температури на $1,8^{\circ} \mathrm{C}$, щзо більше на 13,1\% від середньої багаторічної норми та зменшення кількості опадів на 72,5 мм, або на 23,2\%. Важлива роль у підвищенні продуктивності сільськогосподарських культур належить добривам. В умовах значного подорожчання енертоносіїв та агрохімікатів позакореневі підживлення комплексними водорозчинними добривами стають особливо актуальними. Застосування изього агрозаходу в умовах Лівобережного Лісостепу Украӥни за нестабільного зволоження дає можливість підвищити продуктивність пшениці озимої на 25,8\%, кукурудзи зернової на 12,7\%, буряків иукрових на 15,7\% і суттєво поліпшити якість продукиії.

Ключові слова: водорозчинні добрива, позакореневе підживлення, пшениия озима, кукурудза на зерно, буряки иукрові, урожайність, окуnнiсть затрат.

Постановка проблеми. На Полтавщині, як і в більшій частині Лівобережного Лісостепу України, одним із нерегульованих факторів, що лімітує врожайність сільськогосподарських культур, є волога. За конкретних умов закон мінімуму в нашому регіоні - це рівень вологозабезпеченості рослин, який зумовлює екологічну межу продуктивності. Для формування цього рівня врожаю необхідно враховувати і витрачати інші необхідні ресурси [6].

Родючість грунту - один із найважливіших факторів, що зумовлює межу продуктивності культури та одночасно дає можливість зменшити залежність від несприятливих погодних умов. Нестійкі метеорологічні умови року, за даними багатьох досліджень, зумовлюють коливання урожайності культур у межах плюс-мінус 40-50 \%. Однак ці коливання істотно знижуються (практично вдвічі) на окультурених грунтах, які використовуються за принципом розширеного відтворення ефективної родючості [7].

Інтенсивність ростових процесів польових культур постійно залежить від дії зовнішнього середовища. Негативний вплив мають екстремальні природні умови, передусім, для рослин молодого віку [1]. Одним з ефективних способів (у тому числі й у роки 3 високою вологозабезпеченістю) $є$ застосування добрив. У такому разі витрати вологи на створення одиниці продукції сільськогосподарських культур зменшуються на 10-34 \% [3].

Аналіз основних досліджень і публікацій, у яких започатковано розв'язання проблеми. Згідно з науковими даними, внесення мінеральних добрив під пшеницю озиму після непарових попередників $\epsilon$ надійним i високоефективним прийомом зменшення негативного впливу дефіциту грунтової вологи на величину урожаю. За рахунок внесення добрив прискорюється ріст і розвиток рослин, поліпшується їх укорінення, до того ж корені глибше проникають у грунт, що сприяє більш раціональному використанню запасів продуктивної вологи за настання посушливих умов [5].

За систематичного застосування у сівозміні мінеральних та органічних добрив прирости врожайності сільськогосподарських культур стабілізуються. Можливе зменшення цього при- 
росту в умовах недостатнього водного забезпечення становить лише 1-7 \%, порівняно зі сприятливими умовами водного режиму. На ефективність добрив і стійкість рослин до несприятливих умов істотно впливає вибір оптимальних строків внесення добрив та способів їх застосування. Так, колосові культури, кукурудза, цукрові буряки, соняшник значно підвищують продуктивність за внесення добрив під основний обробіток грунту. Найвищі прирости зерна ячменю ярого та проса одержують за локального застосування туків на глибину 8-12 см під передпосівну культивацію. У такому випадку витрати вологи на створення одиниці врожаю, порівняно з розкидним способом їх внесення, у рослин знижувалися до 15-20\% 3 одночасним підвищенням урожайності.

Отже, вкрай важливо, щоб від початку росту i розвитку рослини мали оптимальний режим грунтового живлення. Суттєвим резервом для цього $\epsilon$ застосування мінеральних добрив у формі комплексних сполук, збалансованих за основними елементами живлення та вмістом у них мікроелементів і регуляторів росту.

Основним джерелом поповнення вологи в грунті $\epsilon$ атмосферні опади. Встановлено, що у ході формування врожаю рослини використовують лише 25-30\% річної кількості опадів; близько $40 \%$ наявних запасів вологи в грунті впродовж вегетаційного періоду випаровується безпосередньо з нього [2].

Одним iз найефективніших заходів в адаптації сільськогосподарських рослин до екстремальних погодних умов (зокрема високих температур та нестачі вологи $€$ позакореневі підживлення).

Мета і завдання досліджень. Метою даної роботи є оцінка зміни врожайності та якості продукції сільськогосподарських культур, покращання фізіологічних властивостей і водоспоживання рослин під дією водорозчинних добрив, а також оцінка їх економічної ефективності.

Завдання: визначити ефективність позакореневого застосування складних водорозчинних добрив.

Матеріали і методи дослідження. Досліди виконувалися в Полтавській державній сільськогосподарській дослідній станції ім. М. І. Вавилова Інституту свинарства і АПВ НААН України.

Грунт дослідної ділянки - чорнозем типовий малогумусний, важко суглинковий; характеризується такими агрохімічними показниками: вміст гумусу у верхньому шарі грунту (0-20 см) - 4,9 \%, азоту (за Корнфільдом) - 15,1 мг, рухомих форм $\mathrm{P}_{2} \mathrm{O}_{5}$ i $\mathrm{K}_{2} \mathrm{O}$ (за Чириковим) - 6,9 мг і 14,9 мг на 100 г грунту, $\mathrm{pH}$ (сольове) - 6,5.

Дослідження проводилися 3 такими сільськогосподарськими культурами, як пшениця озима, кукурудза на зерно та буряки цукрові. Всі культури вирощувалися за інтенсивними технологіями. Площа посівної ділянки - 175 м², облікової - $100 \mathrm{~m}^{2}$. Повторність варіантів у досліді триразова.

Результати досліджень. За останні роки на Полтавщині суттєво змінились температурний i водний режими. Зміна цих показників відбулася як за вегетаційний період, так і по місяцях (табл. 1). Температура у весняні місяці підвищилася в середньому на 8,9-15,7 \%, у літні - на 8,4-10,8 \%, а в осінні - на 13,9-231,6 \%. У листопаді 2012 року середня температура становила $4,4{ }^{0} \mathrm{C}$, а в 2010 році $-8,5{ }^{0} \mathrm{C}$, i тому середній показник місяця за 2008-2012 роки був вищим на 2,5 ${ }^{\circ} \mathrm{C}$ від середньобагаторічного $-1,9{ }^{\circ} \mathrm{C}$. У той же час, відповідно за ці періоди року, кількість опадів зменшилась на 12,2-23,6 \% у весняний період i на 18,5-35,6\% - у літній; за осінній період (а саме у вересні й жовтні) цей показник навіть зріс на 1,1 \% та на 9,5\% відповідно, тоді як у листопаді зменшився на 43,7\%. Вересневі і жовтневі показники за кількістю опадів реально не відображали ситуацію по всіх роках досліджень, так як у вересні 2010 року їх випало 115 мм, а у жовтні 2012 року - 125 мм, що відповідає 2,5 і 2,9 місячним багаторічним нормам. Це і підвищило середній показник. У всі інші роки ці місяці були посушливішими відносно багаторічних даних. Підвищений температурний режим і зменшення кількості опадів негативно впливали на появу сходів, ріст і розвиток озимих та ранніх ярих сільськогосподарських культур.

Як відомо, основна роль у підвищенні продуктивності сільськогосподарських культур належить добривам. Безпосередньо до складу органічної речовини рослин входить лише частина хімічних елементів, що поглинаються кореневою системою. Основна ж роль мінеральних компонентів визначається в регуляції життєвих процесів.

Результати досліджень дали підстави встановити, що водорозчинні добрива сприяють підвищенню функціональної фізіологічної активності рослин, збільшуючи концентрацію хлорофілу в них, підвищуючи ефективність i продуктивність фотосинтезу, зменшуючи інтенсивність дихання (рис. 1). 
1. Середньомісячна температура повітря та кількість опадів за вететаційний період (квітень -листопад)

\begin{tabular}{|c|c|c|c|c|c|c|c|c|c|}
\hline Показник & $\begin{array}{l}\text { Кві- } \\
\text { тень }\end{array}$ & $\begin{array}{l}\text { Тра- } \\
\text { вень }\end{array}$ & $\begin{array}{l}\text { Чер- } \\
\text { вень }\end{array}$ & $\begin{array}{c}\text { Ли- } \\
\text { пень }\end{array}$ & $\begin{array}{l}\text { Сер- } \\
\text { пень }\end{array}$ & $\begin{array}{c}\text { Bере- } \\
\text { сень }\end{array}$ & $\begin{array}{l}\text { Жов- } \\
\text { тень }\end{array}$ & $\begin{array}{l}\text { Лис- } \\
\text { топад }\end{array}$ & $\begin{array}{c}\text { За } \\
\text { вегета- } \\
\text { ційний } \\
\text { період }\end{array}$ \\
\hline \multicolumn{10}{|c|}{ Температура повітря, ${ }^{\circ} \mathrm{C}$} \\
\hline $\begin{array}{c}\text { Середньомісячна за } 49 \text { років } \\
\text { (1964-2012 рр.) }\end{array}$ & 9,5 & 15,7 & 19,4 & 21,3 & 20,2 & 14,6 & 7,9 & 1,9 & 13,8 \\
\hline $\begin{array}{c}\text { Середньомісячна за } 5 \text { років } \\
\text { (2008-2012 pр.) }\end{array}$ & 11,0 & 17,1 & 21,4 & 23,6 & 21,9 & 16,0 & 9,0 & 4,4 & 15,6 \\
\hline \% від середньобагаторічної & 115,7 & 108,9 & 110,3 & 110,8 & 108,4 & 109,6 & 113,9 & 231,6 & 113,0 \\
\hline \multicolumn{10}{|c|}{ Опади, мм } \\
\hline $\begin{array}{c}\text { Середньомісячна за } 49 \text { років } \\
\text { (1964-2012 рр.) }\end{array}$ & 32,6 & 46,6 & 66,6 & 63,4 & 42,7 & 46,4 & 43,2 & 43,5 & 385,0 \\
\hline $\begin{array}{c}\text { Середньомісячна за } 5 \text { років } \\
\text { (2008-2012 pр.) }\end{array}$ & 24,9 & 40,9 & 52,4 & 40,8 & 34,8 & 46,9 & 47,3 & 24,5 & 312,5 \\
\hline \% від середньобагаторічної & 76,4 & 87,8 & 78,7 & 64,4 & 81,5 & 101,1 & 109,5 & 56,3 & 81,2 \\
\hline
\end{tabular}

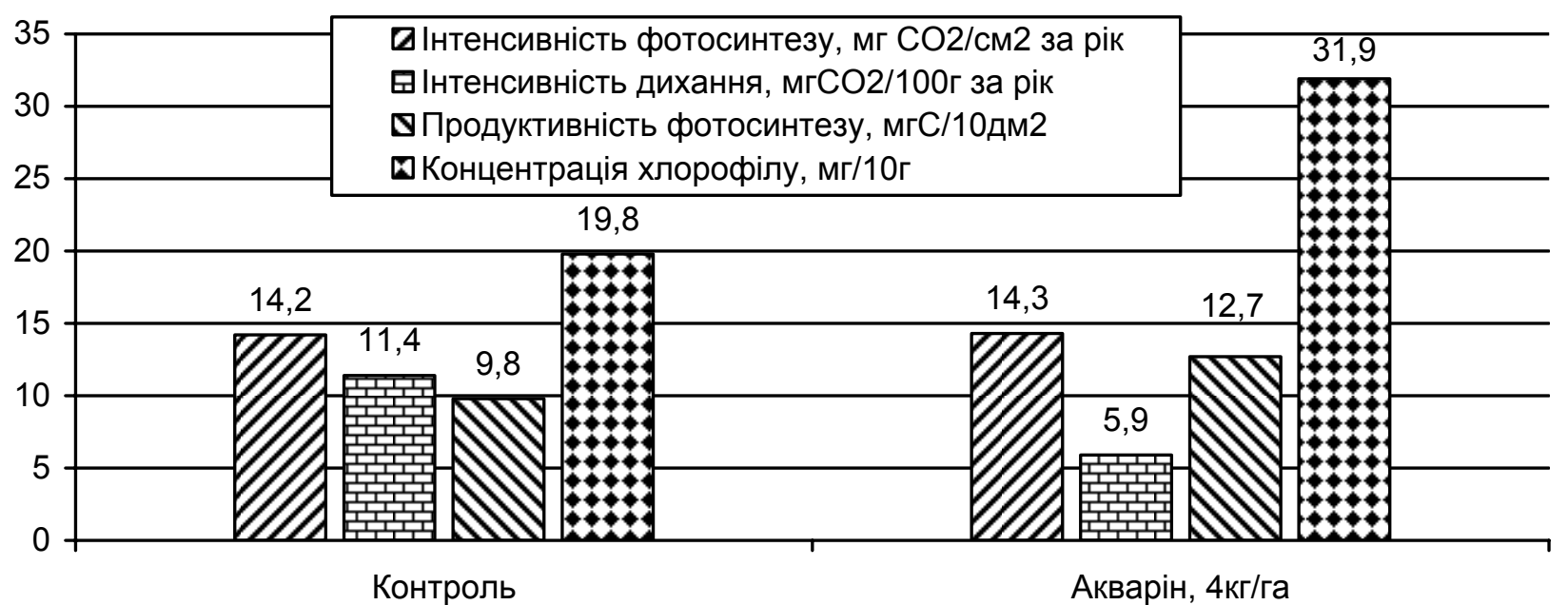

Рис. 1. Фізіолого-біохімічні показники пшениці озимої (фаза цвітіння)

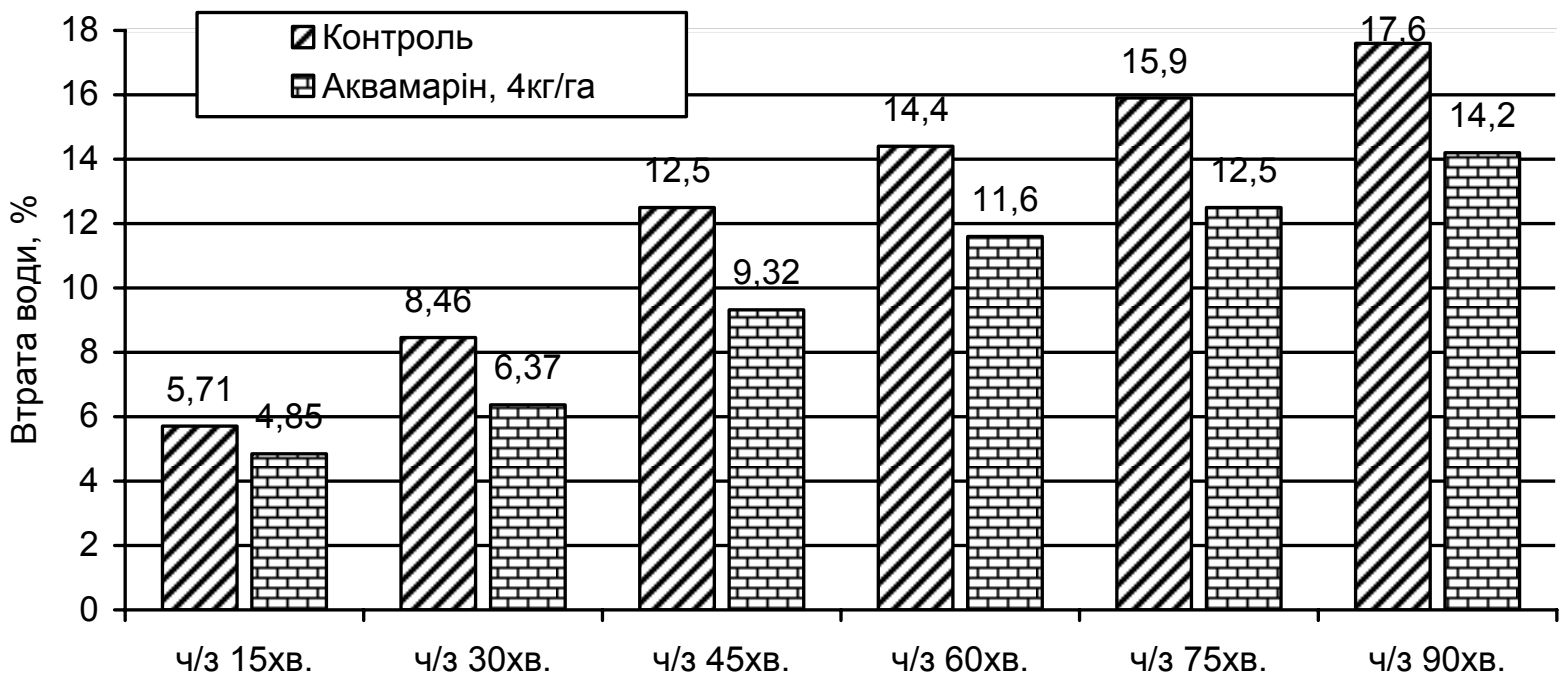

Рис. 2. Втрата води рослинами пшениці озимої, \% (фаза цвітіння) 
СІЛЬСЬКЕ ГОСПОДАРСТВО. РОСЛИННИЦТВО

\section{2. Продуктивність сільськогосподарських культур залежно від системи удобрення}

\begin{tabular}{|c|c|c|c|c|c|c|c|c|}
\hline \multirow[b]{3}{*}{ Показник } & \multicolumn{8}{|c|}{ Культура } \\
\hline & \multicolumn{3}{|c|}{ пшениця озима } & \multicolumn{3}{|c|}{ кукурудза на зерно } & \multicolumn{2}{|c|}{ цукрові буряки } \\
\hline & $\begin{array}{c}\text { контроль } \\
\text { (без } \\
\text { добрив) }\end{array}$ & $1 *$ & $2 * *$ & $\begin{array}{c}\text { контроль } \\
\text { (без } \\
\text { добрив) }\end{array}$ & $1^{*}$ & $\mathrm{~N}_{60} \mathrm{P}_{50} \mathrm{~K}_{50}$ & $\begin{array}{c}\text { контроль } \\
\text { (без } \\
\text { добрив) }\end{array}$ & $\begin{array}{c}1 * \\
2 * * \\
3 * * *\end{array}$ \\
\hline $\begin{array}{c}\text { Урожайність, } \\
\text { ц/га }\end{array}$ & 24,8 & 31,2 & 30,9 & 63,9 & 72,0 & 87,0 & 484 & 540 \\
\hline Вміст білку, \% & 10,0 & 10,8 & 10,9 & - & - & - & - & - \\
\hline Збір цукру, ц/га & - & - & - & - & - & - & 84,0 & 100 \\
\hline $\begin{array}{c}\text { Окупність } 1 \text { грн } \\
\text { затрат, грн }\end{array}$ & - & 5,1 & 4,4 & - & 5,5 & 1,1 & - & 13,1 \\
\hline
\end{tabular}

Примітка: * - позакореневе підживлення рослин «Акваріном» 4 кг/га; ** - позакореневе підживлення рослин «Акваріном» 4 кг/га + сечовина 8 кг/га; *** - позакореневе підживлення рослин «Акваріном» 4 кг/га + сечовина 8 кг/га $+\mathrm{KMnO}_{4} 0,5$ г/га.

Не менш важливим фактором є те, що в такому разі раціональніше витрачається рослинами вода. Втрата вологи рослинами на ділянках, обробленими водорозчинними добривами, менша, ніж на неудобрених (рис. 2). Позакореневе підживлення водорозчинним добривом «Акварін» сприяло не тільки підвищенню урожаю сільськогосподарських культур, але й поліпшило якість зерна пшениці озимої та коренеплодів цукрових буряків (табл. 2). За застосування під пшеницю озиму «Акваріну» 4 кг/га іiі продуктивність зросла на 6,4 ц/га. Сумісне внесення водорозчинного добрива 3 сечовиною збільшило цей показник на 6,1 ц/га; вміст білку в зерні (відносно неудобрених ділянок) підвищився на $0,8 \%$ та $0,9 \%$. Окупність 1 грн затрат становила 5,1 та 4,4 грн відповідно. Порівнюючи вплив основного мінерального удобрення 3 позакореневим підживленням, встановлено, що урожайність зерна кукурудзи була більшою на 15,0 ц/га за основного внесення традиційних азотно-фосфорно-калійних добрив, аніж за позакореневого водорозчинними. Вод-

ночас окупність 1 гривні затрат була в 5 разів меншою. Триразовий обробіток посівів буряків цукрових водорозчинним добривом, сечовиною та перманганатом калію сприяв росту продуктивності коренеплодів відносно неудобрених ділянок на 56,0 ц/га. Збір цукру 31 га зріс на 16,4 ц/га за окупності 1 гривні затрат 13,1 гривнею.

Висновок. За останні п'ять років (2008-2012 років) протягом вегетаційного періоду (квітень листопад) спостерігалося підвищення середньомісячної температури на $1,8{ }^{\circ} \mathrm{C}$, що становить $13,1 \%$, а також зменшення кількості опадів на 72,5 мм (23,2 \%). Застосування водорозчинних добрив сприяє підвищенню фотосинтетичної активності рослин та зменшенню витрат води на формування одиниці врожаю. Позакореневе підживлення рослин комплексними водорозчинними добривами дало можливість збільшити продуктивність пшениці озимої на 25,8 \%, кукурудзи зернової на $12,7 \%$, буряків цукрових - на $15,7 \%$, значно поліпшивши їх якість.

\section{БІБЛІОГРАФІЯ}

1. Акимова Т. В. Влияние локального перегрева на тепло-холодоустойчивость клеток листа и корня растений / Т. В. Акимова, Н. И. Белагурова, А. Ф. Титова // Физиология растений. - 1999. №1(46). - С. 119-124.

2. Іващенко $O$. $O$. Напрями адаптації аграрного виробництва до змін клімату / О. О. Іващенко, O. I. Рудник-Іващенко // Вісник аграрної науки. 2011. - №8. - C. 10-12.

3. Коваленко Н. П. Урожайність і продуктивність пшениці озимої та ячменю озимого у різноротаційних сівозмінах південного Степу України / Н. П. Коваленко, Є. О. Юркевич // Бюлетень інституту зернового господарства. - 2009. - № 37. C. 54-59.

4. Кузнечов E. Н. Влияние макроудобрений на урожай и качество гороха в условиях Волынской области / Е. Н. Кузнецов // Микроелементы в сельськом хозяйстве и медицине: тезисы докладов V Всесоюзного совещания. - Том 3. - УланУдэ, 1965. - С. 33-37.

5. Задонщев А. И. Повышение зимостойкости и продуктивности озимой пшеницы / А. И. Задонцев // Сб. изб. научн. тр. акад. ВАСХНИЛ / ВАСХНИЛ, Всесоюз. научн.-исслед. ин-т. кукурузы; под ред. П. И. Сусидко, Б. П. Соколов, Д. С. Филев [и др.]. - Днепропетровск, 1974. C. $42-54$.

6. Сайко В. Ф. Зерно України / В. Ф. Сайко // Вісник аграрної науки. - 2011. - №9. - С. 5-10. 